\title{
Formulation and Evaluation of Antibacterial, Antifungal Cream of Garlic Oil
}

\author{
Amol Pimpale \\ Researcher, Ravindra Gambhirrao Sapkal College of Pharmacy, \\ Anjaneri, Nashik, Maharashtra, India
}

\begin{abstract}
Plan: The main aim of our research was to develop a novel cream formulation consisting of Garlic oil for the treatment of secondary skin infections.

Prologue: Topical route is most suitable route for skin infections. The development of topical drug delivery systems designed to have systemic effects appears to be beneficial for a number of drugs on account of the several advantages over conventional routes of drug administration.
\end{abstract}

Methodology: A novel cream formulation consisting of Garlic oil was prepared. The formulation was subjected to in-vitro diffusion studies. Microbiological studies were performed to find out the safety of materials used in the formulation.

Result: The developed cream consisting of Garlic oil was found to be safe and effective for the treatment of skin infections.

\section{KEY WORDS: Antibacterial cream, Garlic oil, Antifungal cream \\ INTRODUCTION}

Since the vedic era humans uses medicinal plants material for to cure any disease or to give a satisfactory treatment against that disease. It is like to be says that there is none of a plant on the earth which is without any medicinal property. from this it is shows that the importance plant or a part of a plant a medicine i.e Herbal medicine. The purpose of the current study is also based on the medicinal property of a plant i.e. Garlic (Allium sativum).

Garlic oil is shows a wide range antimicrobial activity. Alliin is present in the garlic oil, when Garlic cloves are crushed then enzyme Allinase is converted alliin into the allicine and allicine is again forms many sulphide compounds. Garlic oil consist of sulfur containing compounds such as allicin, alliin, ajoene, diallyl disulfide, dithiin and Sallylcysteine. These large number of sulfur compounds are gives the smell and taste to the garlic. Diallyl disulfide is an important component in the garlic and being a powerful antibiotic and antifungal compound,<smiles>C=CCSSCC=C</smiles>

Fig Diallyl disulphide

Garlic is very largely used in spice due to its specific odor and taste and it is also reduces blood pressure and Heart problems. from a research it is also found that diallyl disulphide is a drug with broad-spectrum anti-cancer effects. It can inhibit the growth of various tumor cells, such as human colon cancer cells human gastric and breast cancer cells.

\section{MATERIALS AND METHODS}

1. Materials

Propylene glycol, bees wax, stearyl alcohol, cetyl alcohol was purchased from Research-lab fine chem Industries Mumbai. Triethanolamine, propyl paraben, methyl paraben, liquid paraffin was obtained from Pure chem laboratories Pune. stearic acid was purchased from Ozone International Mumbai. And Garlic oil was purchased from Kanta Enterprises Pvt. Ltd New Delhi.

\section{Preparation of cream formulation}

\subsection{Preparation of oil phase}

White Bees Wax, stearic acid, stearyl alcohol, cetyl alcohol were melted in a stainless steel vessel. To this mixture Liquid paraffin were added and allowed to 
melt. The temperature of oil phase maintained between $65-70^{\circ} \mathrm{C}$

\subsection{Preparation of Aqueous phase}

Water was heated to $65-70^{\circ} \mathrm{C}$. In this weighed propylene glycol, triethanolamine, methyl paraben and propyl paraben were added the temperature of the phase was maintained at $65-70^{\circ} \mathrm{C}$.

\section{Development of Cream formulation}

Oil portion was then slowly incorporated into the aqueous phase at $65-70^{\circ} \mathrm{C}$ and mixed for 10 to 15Minutes. When the water and oil phase were at the same temperature, the aqueous phase was slowly added to the oil phase with moderate agitation and was kept stirred until the temperature dropped to $40^{\circ} \mathrm{C}$. and garlic oil was added to it. The emulsion was cooled to room temperature to form a semisolid cream base. $\mathrm{pH}$ of cream kept between 4.5-6.

Table 1: Formula for cream

\begin{tabular}{|l|c|l|l|}
\hline \multicolumn{2}{|c|}{$\begin{array}{c}\text { Part A } \\
\text { (Oily Phase) }\end{array}$} & \multicolumn{2}{c|}{$\begin{array}{c}\text { Part B } \\
\text { (Aqueous Phase) }\end{array}$} \\
\hline \multicolumn{1}{|c|}{ Ingredient } & Quantity & Ingredient & Quantity \\
\hline Stearic Acid & $2.5 \%$ & $\begin{array}{l}\text { Propylene } \\
\text { glycol }\end{array}$ & Tr $5 \%$ \\
\hline $\begin{array}{l}\text { White Bees } \\
\text { Wax }\end{array}$ & $1.5 \%$ & $\begin{array}{l}\text { Triethan } \\
\text { olamine }\end{array}$ & R 2\%ea \\
\hline Stearyl Alcohol & $5 \%$ & $\begin{array}{l}\text { Methyl } \\
\text { Paraben }\end{array}$ & $0.01 \%$ \\
\hline Cetyl Alcohol & $6.5 \%$ & $\begin{array}{l}\text { Propyl } \\
\text { paraben }\end{array}$ & \begin{tabular}{l}
$0.04 \%$ \\
\hline Mineral Oil
\end{tabular} \\
\hline Garlic Oil & $5 \%$ & Water & $\begin{array}{l}\text { Up to } \\
100 \%\end{array}$ \\
\hline
\end{tabular}

\section{Evaluation parameters}

Take about 1 gram of cream in a clean petri dish and observe visually

\subsection{Physical examination}

The prepared topical creams were inspected visually for their color, homogeneity, consistency, spreadability and phase separation. The $\mathrm{pH}$ was measured in each cream, using a $\mathrm{pH}$ meter, which was calibrated before each use with standard buffer solutions at $\mathrm{pH} \mathrm{4,7,9.} \mathrm{The} \mathrm{electrode} \mathrm{was} \mathrm{inserted} \mathrm{in}$ to the sample $10 \mathrm{~min}$ priors to taking the reading at room temperature. The $\mathrm{pH}$ of a topical preparation should be within the $\mathrm{pH}$ range corresponding to the $\mathrm{pH}$ of the skin, namely, 4.5- 6.5.

\subsection{Viscosity}

The viscosity of formulated creams was measured by Brook field Viscometer LVD using spindle S 94 at varying speed and shear rates. The measurements were done over the range of speed setting from 0.10 , $0.20,0.30,0.40$ and $0.50 \mathrm{rpm}$ in $60 \mathrm{~s}$ between two successive speeds as equilibration with shear rate ranging from $0.20 \mathrm{~s}-1$ to $1.0 \mathrm{~s}-1$. Viscosity determinations were performed at room temperature.

\subsection{Tube extrudability}

In the present study, the method adopted for evaluating cream formulation for extrudability was based upon the quantity in percentage cream extruded from tube on application of finger pressure 7. More quantity extruded better was extrudability. The formulation under study was filled in a clean, lacquered aluminium collapsible $5 \mathrm{gm}$ tube with a nasal tip of $5 \mathrm{~mm}$ opening and applied the pressure on the tube by the help of finger. Tube extrudability was then determined by measuring the amount of cream extruded through the tip when a pressure was applied on a tube.

\section{Microbiological studies}

Topical formulation with broad, non-resistance promoting activity against staphylococci, streptococci, dermatophytes or yeast or molds can be of great use in dermatology preparation were infections are often mixed. Since formulation containing antimicrobial agents as active moiety, it is likely to protect from microbial growth . To determine the activity of formulation is subject to study the prepared formulation with standard method called Disk diffusion method and the inhibition zone diameters were measured with the help of zone reader.

\section{RESULTS}

\section{Physical Evaluation}

The cream is white, appealing appearance and smooth texture, and they were all homogenous with no signs of phase separation.

\section{2. pH measurement}

The $\mathrm{pH}$ of the cream was found to 6.2. The $\mathrm{pH}$ should not be too acidic as it may cause skin irritation and should not be too alkaline as it may cause scaly skin.

\section{3. viscocity measurement}

Viscocity was measured by Brookfield viscometer and it was found to be $67540 \mathrm{cps}$. 


\section{Microbiological studies}

From the microbial study it was found that the cream showing good effects on microbial growth and the zone of inhibition was calculated by zone reader. The zone of inhibition of candida albicans was $42.32 \mathrm{~mm}$ and of E.coli it was $34.16 \mathrm{~mm}$.

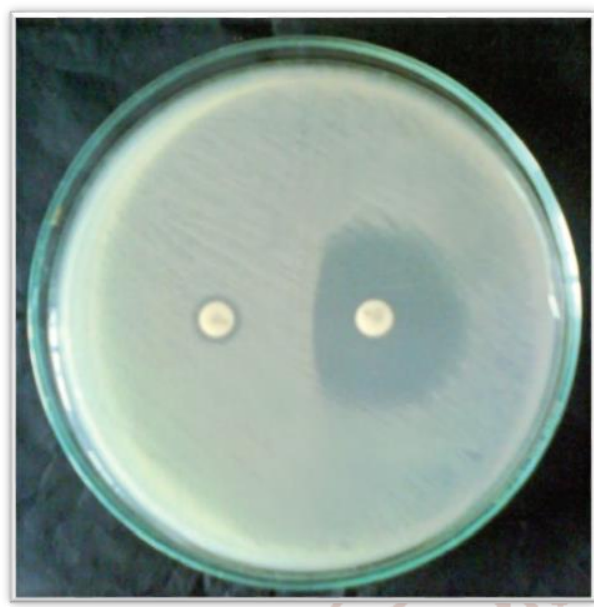

Against candida albicans

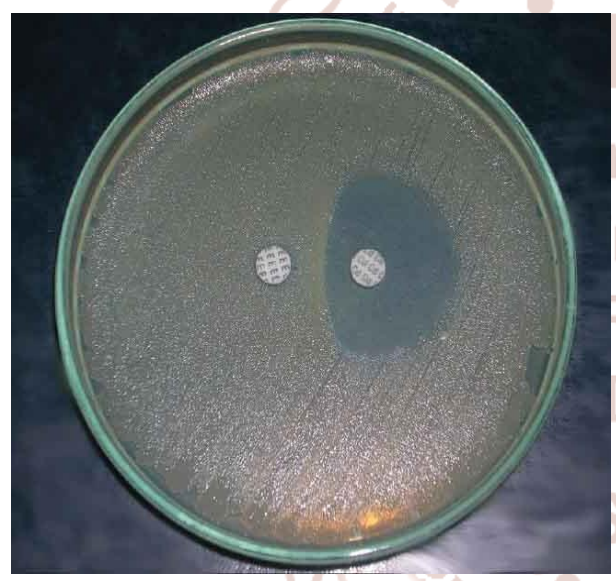

Against E.coli

Fig: formulated cream showing zone of inhibition

Table2. Microbial studies

\begin{tabular}{|c|c|c|}
\hline bacteria & Candida albicans & E.coli \\
\hline Zone of inhibition & $42.32 \mathrm{~mm}$ & $34.16 \mathrm{~mm}$ \\
\hline
\end{tabular}

\section{DISCUSSION}

From the above compiled data the study clearly shows that the formulation is showing good in-vitro antifungal activity against E.coli and candida albicans.

\section{CONCLUSION}

The formulation of antimicrobial agents along with Garlic oil exhibited enhanced rate of diffusion and antibacterial activity. The results of different chemical and physical tests of cream showed that it could use topically in order to protect against skin infections caused by fungus or bacteria.

\section{ACKNOWLEDGEMENT}

The authors wish to thank Sapkal college of pharmacy for providing facilities and carry out research work and also to Prof. Mayur sawant, Priyanka Bediskar, sayali thormise for their valuable support and guidance, and also thankful to Sushmita pingale and Sameer shinde.

\section{REFERENCES}

1. Agis F. Kydonieus. Transdermal Delivery of Drugs, Volume 1, CRC Press, Bocaraton, 1987; 168.

2. Patel J, Patel B, Banwait H, Parmar K, Patel M, Formulation and evaluation of topical aceclofenac gel using Different gelling agent, International Journal of Drug Development \& Research 2011; 3:156- 164 .

3. Parmar RB, Baria AH, Faldu SD, Tank HM, Design and Evaluation of Poly-herbal Formulation in Semisolid Dosage Form for its Antibacterial Activity, Journal of Pharmacy Research 2009; 2:1095-1097.

4. More $\|\mathrm{BH}$,$\| Sakharwade SN, Tembhurne SV,$ Sakarkar DM, Evaluation for skin irritancy testing of developed formulations containing extract of Buteamonosperma for its topical application, International Journal of Toxicology and Applied Pharmacology 2013; 3:10-13.

5. OECD 404, Guideline for the testing of Chemicals.

6. Sanna V, Peana AT, Mario D, Moretti L, Development of new topical formulations of diphenhydramine hydrochloride: In vitro Diffusion and In vivo Preliminary studies, International journal of Pharm Tech Research, 2010; 2: 863- 889. Biopharmaceutics 2008; 68:380 -389.

7. Mei X. Chen, Kenneth S. Alexander, and Gabriella Baki, Formulation and Evaluation of Antibacterial Creams and Gels Containing Metal Ions for Topical Application, Hindawi Publishing Corporation. Journal of Pharmaceutics, Volume 2016, Article ID 5754349

8. HETTY LENDORA MAHA1*, KASMIRUL RAMLAN SINAGA, MASFRIA, FORMULATION AND EVALUATION OF MICONAZOLE NITRATE NANOEMULSION AND CREAM, Asian J Pharm Clin Res, Vol 11, Issue 3, 2018, 319-321 
International Journal of Trend in Scientific Research and Development (IJTSRD) ISSN: 2456-6470

9. A. Premkumar, T. Muthukumaran, V. Ganesan , Shanmugam R, Priyanka D.L, FORMULATION AND EVALUATION OF CREAM CONTAINING ANTIFUNGALAGENTS, ANTIBACTERIAL AGENTS AND CORTICOSTEROIDS , Hygeia.J.D.Med.6 (2) October 2014; 5-16

extracts and essential oils, Science against microbial pathogens: communicating current research and technological advances,1179-1185

11. B. DETHIER*, K. NOTT*, M.-L. FAUCONNIER*, (BIO) SYNTHESIS, EXTRACTION AND PURIFICATION OF GARLIC DERIVATIVES SHOWING

10. M. A. Calvo, E. L. Arosemena, C. Shiva and C. Adelantado, Antimicrobial activity of plant natural THERAPEUTIC PROPERTIES, Comm. Appl. Biol. Sci, XX/X, 2013.

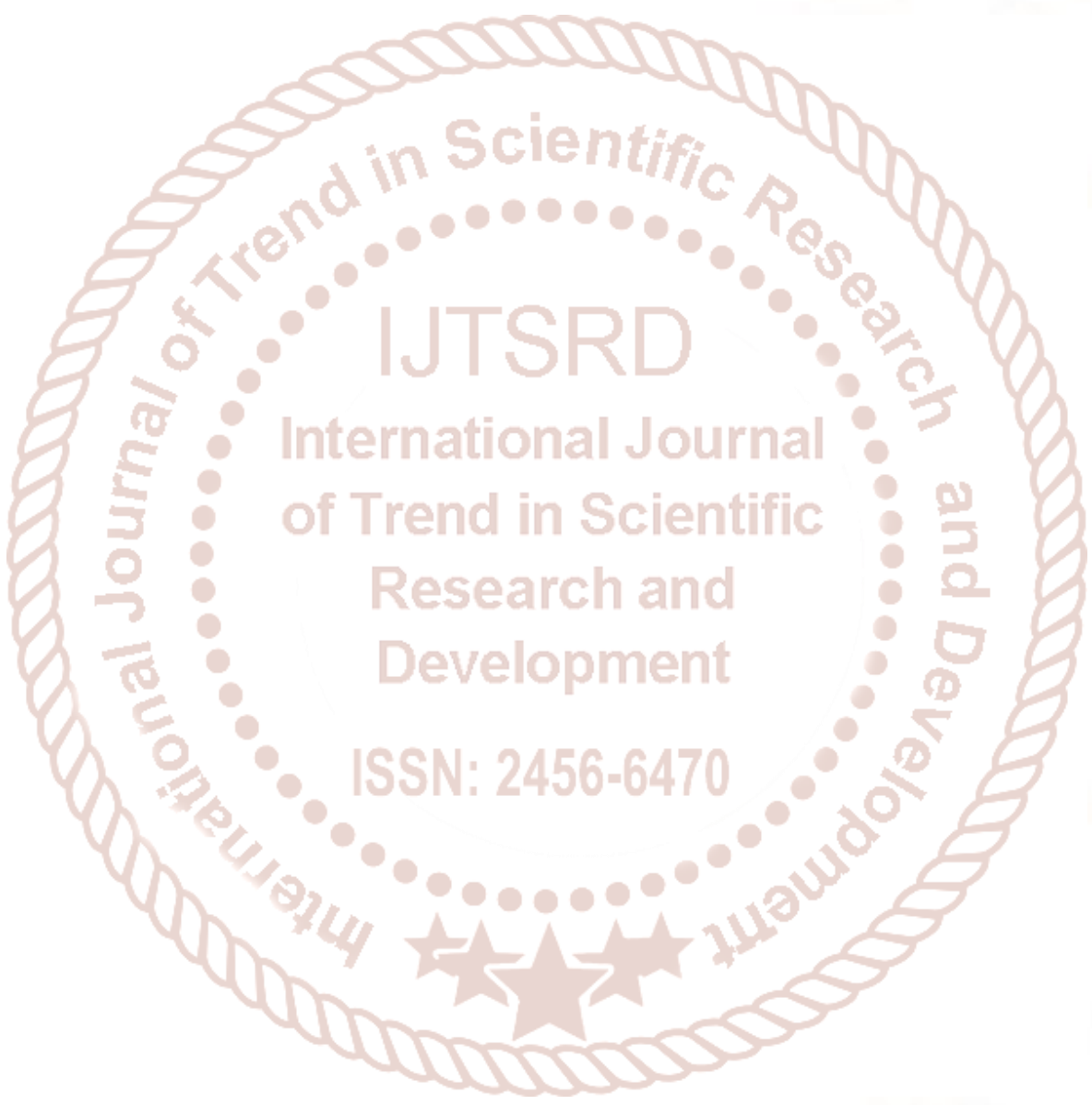

